\title{
Characterization of Custard Apple (Annona squamosa L.) Genotypes at Northern Bastar of Chhattisgarh, India
}

\author{
Jeevan Lal Nag ${ }^{1 *}$, N. Shukla ${ }^{2}$ and Ajay Tiwari ${ }^{3}$ \\ ${ }^{1}$ College of Agriculture and Research Station, Kanker, Chhattisgarh-494 334, India \\ ${ }^{2}$ Department of Horticulture, CoA, IGKV, Raipur (C.G.)-492012, India \\ ${ }^{3}$ Department of Genetics \& Plant breeding, CoA, IGKV, Raipur (C.G.), India 492012, India \\ *Corresponding author
}

\section{Keywords \\ GCV, PCV, \\ Variability, \\ Heritability, \\ Genetic advance, \\ Genotype, Custard apple}

\section{Article Info}

Accepted:

18 January 2018

Available Online:

10 February 2018

\section{A B S T R A C T}

The field experiment was conducted at Research cum Instructional Farm, College of Agriculture and Research Station, Singarbhat, Kanker, Indira Gandhi Krishi Vishwavidyalaya, Raipur (Chhattisgarh) during Kharif 2013-14. The experiment was laid out in Randomized Block Complete Design with four replication, in-situ sixty genotypes of about 10 year age were selected for investigation, which were found as wild seedling plants on forest land and rice bunds. Investigation was carried out at Antagarh, Bhanupratappur, Charama, Durgkondal, Kanker, Koylibeda and Narharpur blocks of District- Kanker (Chhattisgarh). The treatments comprised of sixty genotypes with different character viz number of alternate leaf, length of leaf $(\mathrm{cm})$, number of flowers per branches, days to $50 \%$ maturity, total number of fruits, fruit width $(\mathrm{cm})$, fruit length $(\mathrm{cm})$, fruit weight $(\mathrm{g})$, length of pedicel $(\mathrm{cm})$, pedicel thickness, length of pericarp $(\mathrm{cm})$, weight of pericarp $(\mathrm{g})$, seed length $(\mathrm{mm})$, seed width $(\mathrm{mm})$, number of seeds per fruit, seed weight $(\mathrm{g})$, pulp weight $(\mathrm{g})$, areole weight $(\mathrm{g})$, number of fruits per tree and fruit yield per plant $(\mathrm{kg})$. Findings of analysis of variance revealed significant mean squares due to genotypes for all the traits under the study indicated the existence of sufficient genetic variability for the traits. The highest Genotypic and phenotypic coefficient of variation (GCV and PCV) estimates were observed for pulp weight, which is followed by areole weight (51.47\% and 51.80) and fruit weight (44.70\% and 45.10). The highest Genetic advance was observed for fruit weight (212.64) followed by pulp weight (122.27), areole weight (82.55). High heritability coupled with high genetic advance was found for was recorded for the character pulp weight, followed by areole weight, fruit weight and weight of pericarp. Rest of the traits exhibited medium to low genetic advance coupled with high to low heritability indicated the role of non-additive genetic variance in their expression.

\section{Introduction}

Custard apple (Annona squamosa L.), also known as Sitaphal or Sharifa is an important dryland fruit crop in India and belongs to family 'Annonaceae' having chromosome number $2 \mathrm{n}=14$. The fruit tree belongs to tropical climate and is native of tropical America and surrounding regions. Annona means year's harvest and squamosa means scaly referring to the scale like structure of the fruit surface. Custard apple tree has been naturalized in the Deccan plateau due to its hardy nature and hence, it is an important 
dryland fruit crop. It is cultivated in Maharashtra, Gujarat, Madhya Pradesh, Andhra Pradesh, Chhattisgarh, Karnataka, Bihar, Orissa, Assam and Tamil Nadu. Besides India, it is common in China, Phillippines, Egypt and Central Africa. In India, it is presently grown in an area of about 29.87 thousand hectares with a production of 228.37 metric tones and the average productivity is $765 \mathrm{q} / \mathrm{ha}$ and it ranges from $673 \mathrm{q} / \mathrm{ha}$ in Andhra Pradesh to $685 \mathrm{q} / \mathrm{ha}$ in Maharashtra (2014-15). Chhattisgarh and Maharashtra occupies 55.74 per cent of the total area in the country. Whereas Gujarat covered 5.34 thousand hectare and the average productivity is $768 \mathrm{q} / \mathrm{ha}$ (Chandra, 2010). Chhattisgarh, state of India occupies an area of approximately 7.99 thousand hectare with an annual production of 39.73 metric tones having the productivity of $497.25 \mathrm{q} /$ ha under custard apple. In the range of forest scattered across Jagdalpur, Beejapur, Dantewada, Kanker, Dhamtari, Rajnandgaon, Durg, Jashpur, Surguja and Bilaspur districts, only Kanker district is blessed with natural biodiversity of the custard apple. Its wild land races are found distributed all along as a natural stand over an area of about 7.20 thousand hectare with an annual production of 35.60 metric tones having the productivity of 494.45 q/ha (Anonymous, 2013). The edible portion or pulp is creamy or custard like, granular, with a good blend of sweetness, possessing pleasant flavor and mild aroma have a universal liking, being rich in carbohydrates $23.0 \mathrm{~g}$ per100 g fruits. The fruit is reported to have moisture $70.5 \mathrm{~g}$, protein 1.6 $\mathrm{g}$, fat $0.4 \mathrm{~g}$, minerals $0.9 \mathrm{~g}$, fiber $3.1 \mathrm{~g}$, calcium $17.0 \mathrm{mg}$, phosphorous $47.1 \mathrm{mg}$, iron $1.5 \mathrm{mg}$, thiamine $0.07 \mathrm{mg}$, riboflavin $0.17 \mathrm{mg}$, niacin $1.30 \mathrm{mg}$, Vitamin C $37.0 \mathrm{mg}$ and energy $104 \mathrm{Kcal}$ Gopalan et al., (1987) and Singh, (1995). The evolution of custard apple through natural and human selection in diverse elevation zones and under different cropping systems with involvement of honey bees being the carrier of cross pollination has resulted in a wide variety of locally adapted landraces. These landraces have evolved over years to fit into local cropping patterns and diverse end uses and represent a wide range of patterns of crop diversity. The knowledge of patterns of genetic variation of a crop species in any given region or country is very important for planning future germplasm exploration missions and thereafter it's efficient utilization in crop improvement programme. Assessment of genetic variability for yield and its components is useful to predict the extent of improvement possible for fruits yield and other important characters. The heritability estimates and genetic advance proved to be the important parameters for isolating the desirable genotypes. Heritability provides information on contribution of genotypic variance to the corresponding phenotypic variance while, genetic advance reflects genetic architecture of any population. High genetic advance associated with high heritability gives an idea of true heritable traits for better plant selection during breeding programme.

\section{Materials and Methods}

An experiment comprised of 60 genotype accessions (Table 1) was conducted at 10 years In-situ plantation at Northern Bastar, Research cum Instructional Farm College of Agriculture and Research Station, Singarbhat, Kanker, Indira Gandhi Krishi Vishwavidyalaya, Raipur (Chhattisgarh) during Kharif 2013-14. The experiment was laid out in Randomized Complete Block Design (RCBD) with four replications recommended package of practices were applied to raise the normal crop. Observations were recorded on one randomly selected competitive plants from each genotype, in each replication on 20 characters viz., number of alternate leaf, length of leaf $(\mathrm{cm})$, number of flowers per branch, days to $50 \%$ maturity, 
total number of fruits, fruit width $(\mathrm{cm})$, fruit length $(\mathrm{cm})$, fruit weight $(\mathrm{g})$, length of pedicel (cm), pedicel thickness, length of pericarp $(\mathrm{cm})$, weight of pericarp $(\mathrm{g})$, seed length $(\mathrm{mm})$, seed width $(\mathrm{mm})$, number of seeds per fruit, seed weight $(\mathrm{g})$, pulp weight $(\mathrm{g})$, areole weight $(\mathrm{g})$, number of fruits per tree and fruit yield per plant $(\mathrm{kg})$. The statistical analysis for genetic variability was done as per the method given by Burton (1952). Heritability in broad sense (Hanson et al., 1956) and genetic advance (Johnson et al., 1955) were calculated.

\section{Results and Discussion}

\section{Analysis of variance}

The Analysis of variance (ANOVA) worked out for quantitative traits with respect to fruit yield and its components in custard apple indicated that the mean sum of squares due to genotypes were highly significant for all the characters. This is an indication of existence of sufficient variability for the traits (Table 2).

\section{Genetic variability parameters}

Genetic parameters of variation for fruit yield and its components in custard apple are presented in table 3 . The measurement of existing variability in genetic material has been the basic requirement of a breeding programme. In the present investigation, a wide range of variability was observed for nearly all the traits viz., number of alternate leaf, length of leaf, number of flowers per branch, days to $50 \%$ maturity, seed length, seed width, number of seeds per fruit, fruit yield per plant, weight of pulp, weight of areole, number of fruits per tree and weight of seed in total gene pool, indicating the existence of sufficient variability among the genotypes for the quantitative traits. These findings are in general agreement with the findings of Saulo et al., (2006), Keny and
Paulo (2009), Paulo et al., (2009) and Bhatnagar et al., (2012).

\section{Genotypic and phenotypic coefficient of variation}

The genotypic and phenotypic coefficients of variation for quantitative traits have been computed by 2013-14 and presented in Table 3. Genotypic and phenotypic coefficients of variation are simple measures of variability; these measures are commonly used for the assessment of variability. The relative values of these types of coefficient gives an idea about the magnitude of variability present in a genetic population. Thus, the components of variation such as genotypic coefficient of variation $(\mathrm{GCV})$ and phenotypic coefficient of variation (PCV) were computed. The phenotypic coefficients of variation were marginally higher than the corresponding genotypic coefficients of variation indicated the influence of environment in the expression of the characters under study. Genotypic coefficient of variation (GCV) and phenotypic coefficient of variation (PCV) are categorized as low (less than 10\%), moderate (10-20\%) and high (more than 20\%) as suggested by Sivasubramanium and Madhavamenon (1973).

The highest (GCV 52.16\%) and PCV 52.46) was observed for pulp weight, which is followed by areole weight $(51.47 \%$ and $51.80)$, fruit weight $(44.70 \%$ and 45.10$)$, length of pedicel (30.67 \% and $31.27 \%$ ), pedicel thickness $(29.61 \%$ and $30.16 \%)$, weight of pericarp $(29.60 \%$ and $30.22 \%)$, length of pericarp (29.29\% and $29.61 \%)$, total number of fruits per plant $(23.08 \%$ and 24.35$)$ and fruit width $(20.19 \%$ and $21.07 \%)$. The moderate GCV and PCV were observed for fruit yield per plant (16.13\% and $17.04 \%)$ which is followed by number of flower per branches (10.71\% and $12.31 \%)$, length of leaf $(10.59 \%$ and $14.88 \%)$ and seed length $(10.37 \%$ and $20.08 \%)$. Rest of the traits 
exhibited low GCV and PCV estimates. The results on genotypic and phenotypic coefficient of variation clearly indicated that the phenotypic coefficients of variation in general were slightly higher than the genotypic coefficients of variation for all the characters indicating the substantial influence of environment in the expression of the characters the character high GCV and PCV was observed pulp weight, areole weight and fruit weight GCV and PCV. The moderate GCV and PCV were observed for fruit yield per plant and number of flower per branches. The GCV and PCV were low for the characters viz., days to $50 \%$ maturity, fruits per tree, number of seeds per fruit and number of alternate leaf. These findings are in general agreement with the findings of Jagtap and Kokate (1991), George et al., (1999), Carvalho et al., (2000) and Wang et al., (2001).

\section{Heritability and genetic advance}

Heritability governs the resemblance between parents and their progeny, whereas, the genetic advance provides the knowledge about expected gain for a particular character after selection. Heritability suggests the relative role of genetic factors in expression of phenotypes and also acts as an index of transmissibility of a particular trait to its off springs. However, the knowledge of heritability alone does not help in formulating concrete breeding programme, genetic advance along with heritability helps to ascertain the possible genetic control for any particular trait. The nature and extent of the inherent ability of a genotype for a character is an important parameter determining the extent of improvement of any field and fruit crop species. Heritability and genetic advance are the important genetic parameters for selecting a genotype that permit greater effectiveness of selection by separating out environmental influence from total variability.
Heritability estimates along with genetic advance are normally more useful in predicting the gain under selection than that of heritability alone. However, it is not necessary that a character showing high heritability will also exhibit high genetic advance (Johnson et al., 1955). An attempt has been made in the present investigation to estimate heritability in broad sense and categorized as low $(<50 \%)$, moderate $(50-70 \%)$ and high $(>70 \%)$ as suggested by Robinson (1966).

\section{Heritability for fruit yield and its components}

The data computed from 2013-14 observation on heritability for quantitative traits have been presented in Table 3. In present investigation, the highest heritability estimate was recorded for the character pulp weight $(99.00 \%)$, areole weight $(99.00 \%)$, fruit weight $(98.00 \%)$, length of pericarp $(98.00 \%)$, weight of pericarp $(96.00 \%)$, length of pedicel $(96.00 \%)$, pedicel thickness $(96.00 \%)$, fruit width $(92.00 \%)$, total number of fruits per plant $(90.00 \%)$, fruit yield per plant $(90.00 \%)$, fruit length $(88.00 \%)$, number of flowers per branch $(76.00 \%)$ and seed length $(76.00 \%)$.

The moderate heritability was observed for the character seed weight $(67.00 \%)$, number of fruits per tree $(65.00 \%)$, number of seeds per fruit $(62.00 \%)$ and seed width $(62.00 \%)$ and length of leaf $(51.00 \%)$. Rest of the traits exhibited low heritability estimates. These findings are in general agreement with the findings of Carvalho et al., (2000) and Wang et al., (2001).

\section{Genetic advance}

The genetic advance for computed from have been presented in Table 3. The magnitude of genetic advance was categorized as high (> $20 \%)$, moderate $(10 \%-20 \%)$ and low (< $10 \%)$. 
The highest genetic advance was observed for fruit weight (212.64) followed by pulp weight (122.27), areole weight (82.55), number of fruits per tree (34.84), fruit yield per plant (35.81) and number of alternate leaf (24.58).
The moderate genetic advance was not observed for the character, rest of the traits showed low genetic advance by George et al., (1999).

Table.1 The list of experimental material used for genetic variability analysis in custard apple

\begin{tabular}{|c|c|c|c|}
\hline S. No. & Name of Genotypes & S. No. & Name of Genotypes \\
\hline 1 & IGCA-1 & 31 & IGCA-31 \\
\hline 2 & IGCA-2 & 32 & IGCA-32 \\
\hline 3 & IGCA-3 & 33 & IGCA-33 \\
\hline 4 & IGCA-4 & 34 & IGCA-34 \\
\hline 5 & IGCA-5 & 35 & IGCA-35 \\
\hline 6 & IGCA-6 & 36 & IGCA-36 \\
\hline 7 & IGCA-7 & 37 & IGCA-37 \\
\hline 8 & IGCA-8 & 38 & IGCA-38 \\
\hline 9 & IGCA-9 & 39 & IGCA-39 \\
\hline 10 & IGCA-10 & 40 & IGCA-40 \\
\hline 11 & IGCA-11 & 41 & IGCA-41 \\
\hline 12 & IGCA-12 & 42 & IGCA-42 \\
\hline 13 & IGCA-13 & 44 & IGCA-43 \\
\hline 14 & IGCA-14 & 44 & IGCA-44 \\
\hline 15 & IGCA-15 & 45 & IGCA-45 \\
\hline 16 & IGCA-16 & 46 & IGCA-46 \\
\hline 17 & IGCA-17 & 47 & IGCA-47 \\
\hline 18 & IGCA-18 & 48 & IGCA-48 \\
\hline 19 & IGCA-19 & 49 & IGCA-49 \\
\hline 20 & IGCA-20 & 50 & IGCA-50 \\
\hline 21 & IGCA-21 & 51 & IGCA-51 \\
\hline 22 & IGCA-22 & 52 & IGCA-52 \\
\hline 23 & IGCA-23 & 53 & IGCA-53 \\
\hline 24 & IGCA-24 & 54 & IGCA-54 \\
\hline 25 & IGCA-25 & 55 & IGCA-55 \\
\hline 26 & IGCA-26 & 56 & IGCA-56 \\
\hline 27 & IGCA-27 & 57 & IGCA-57 \\
\hline 28 & IGCA-28 & 58 & IGCA-58 \\
\hline 29 & IGCA-29 & 59 & IGCA-59 \\
\hline 30 & IGCA-30 & 60 & IGCA-60 \\
\hline
\end{tabular}


Table.2 Analysis of variance for quantitative traits of fruit yield and its components in custard apple during the year 2013-14

\begin{tabular}{|c|c|c|c|c|c|c|c|c|c|c|c|}
\hline \multirow{3}{*}{$\begin{array}{l}\text { Source of } \\
\text { Variation }\end{array}$} & d.f. & \multicolumn{10}{|c|}{ Mean Sum of Squares } \\
\hline & & 1 & 2 & 3 & 4 & 5 & 6 & 7 & 8 & 9 & 10 \\
\hline & & $\begin{array}{c}\text { No. of } \\
\text { Alternate } \\
\text { Leaf }\end{array}$ & $\begin{array}{l}\text { Length } \\
\text { of Leaf } \\
(\mathrm{cm})\end{array}$ & $\begin{array}{l}\text { No. of } \\
\text { Flowers } \\
\text { Per } \\
\text { Branch }\end{array}$ & $\begin{array}{c}\text { Days to } \\
50 \% \\
\text { Maturity }\end{array}$ & $\begin{array}{l}\text { Total No. } \\
\text { of Fruits }\end{array}$ & $\begin{array}{l}\text { Fruit } \\
\text { Width } \\
(\mathrm{cm})\end{array}$ & $\begin{array}{l}\text { Fruit } \\
\text { Length } \\
(\mathrm{cm})\end{array}$ & $\begin{array}{l}\text { Fruit Weight } \\
(\mathrm{g})\end{array}$ & $\begin{array}{l}\text { Length } \\
\text { of } \\
\text { Pedicel } \\
(\mathrm{cm})\end{array}$ & $\begin{array}{c}\text { Pedicel } \\
\text { Thickness }\end{array}$ \\
\hline Replication & 3 & 1354.9677 & 1.1402 & 9.5444 & 20.9500 & 0.1333 & 0.2275 & 0.9158 & 104.9708 & 0.0592 & 5.6500 \\
\hline Treatment & 59 & $8179.1841 * *$ & $1.5170 * *$ & $69.6565 * *$ & $63.9862 * *$ & $83.6768 * *$ & $1.7590 * *$ & $10.4101 * *$ & $45424.8906 * *$ & $1.6904 * *$ & $94.4658 * *$ \\
\hline Error & 177 & 486.7686 & 0.3210 & 4.1716 & 42.6280 & 1.4384 & 0.1164 & 0.3450 & 193.4737 & 0.0326 & 2.2573 \\
\hline Total & 239 & & & & & & & & & & \\
\hline
\end{tabular}

\begin{tabular}{|c|c|c|c|c|c|c|c|c|c|c|c|}
\hline \multirow{3}{*}{$\begin{array}{l}\text { Source of } \\
\text { Variation }\end{array}$} & d.f. & \multicolumn{10}{|c|}{ Mean Sum of Squares } \\
\hline & & 11 & 12 & 13 & 14 & 15 & 16 & 17 & 18 & 19 & 20 \\
\hline & & $\begin{array}{l}\text { Length } \\
\text { of } \\
\text { Pericarp } \\
(\mathrm{cm})\end{array}$ & $\begin{array}{l}\text { Weight } \\
\text { of } \\
\text { Pericarp } \\
\text { (g) }\end{array}$ & $\begin{array}{l}\text { Seed } \\
\text { Length } \\
(\mathrm{mm})\end{array}$ & $\begin{array}{c}\text { Seed } \\
\text { Width } \\
(\mathrm{mm})\end{array}$ & $\begin{array}{l}\text { No. of } \\
\text { Seeds/ } \\
\text { Fruit }\end{array}$ & $\begin{array}{c}\text { Seed } \\
\text { Weight }(g)\end{array}$ & $\begin{array}{l}\text { Pulp Weight } \\
(\mathrm{g})\end{array}$ & $\begin{array}{c}\text { Areole } \\
\text { Weight }(g)\end{array}$ & $\begin{array}{c}\text { No. of } \\
\text { Fruits/ Tree }\end{array}$ & $\begin{array}{c}\text { Fruit Yield/ } \\
\text { Plant (kg) }\end{array}$ \\
\hline Replication & 3 & 0.0388 & 0.1495 & 1.1611 & 0.9486 & 4.1889 & 13.1081 & 58.1511 & 38.2642 & 415.0278 & 56.1794 \\
\hline Treatment & 59 & $1.4461 * *$ & $4.5969 * *$ & $31.4150 * *$ & $3.0008 * *$ & $29.0751 * *$ & $822.5460 * *$ & $14300.2822 * *$ & $6453.8711 * *$ & $1752.9929 * *$ & $1315.5424 * *$ \\
\hline Error & 177 & 0.0149 & 0.0614 & 1.7798 & 0.4232 & 3.1465 & 7.4679 & 43.3687 & 23.6971 & 236.4402 & 35.7307 \\
\hline Total & 239 & & & & & & & & & & \\
\hline
\end{tabular}


Table.3 Genetic parameters of variation for fruit yield and its components in custard apple for quantitative traits

\begin{tabular}{|c|c|c|c|c|c|c|c|c|c|}
\hline \multirow[t]{2}{*}{ S. No. } & \multirow{2}{*}{ Characters } & \multirow{2}{*}{$\frac{\text { Grand }}{\frac{\text { mean }}{\mathrm{X}}}$} & \multicolumn{2}{|c|}{ Range } & \multirow{2}{*}{ GCV } & \multirow{2}{*}{ PCV } & \multirow{2}{*}{$\begin{array}{l}\text { Heritability } \\
(\%)\end{array}$} & \multirow{2}{*}{$\begin{array}{l}\text { Genetic } \\
\text { advance }\end{array}$} & \multirow{2}{*}{$\begin{array}{c}\text { Genetic } \\
\text { advance as } \\
\% \text { of mean }\end{array}$} \\
\hline & & & Min. & Max. & & & & & \\
\hline 1 & No. of Alternate Leaf & 320.75 & 236.75 & 359.00 & 7.31 & 14.38 & 26.00 & 24.58 & 7.66 \\
\hline 2 & Length of Leaf $(\mathrm{cm})$ & 6.77 & 5.18 & 8.15 & 10.59 & 14.88 & 51.00 & 1.05 & 15.52 \\
\hline 3 & Flowers Per branches & 29.67 & 25.25 & 42.00 & 10.71 & 12.31 & 76.00 & 5.69 & 19.18 \\
\hline 4 & Days to $50 \%$ maturity & 115.45 & 106.00 & 124.00 & 2.67 & 4.76 & 31.00 & 3.56 & 3.09 \\
\hline 5 & Total No. of fruits/ plant & 17.96 & 11.00 & 32.00 & 23.08 & 24.35 & 90.00 & 8.10 & 45.07 \\
\hline 6 & Fruit width $(\mathrm{cm})$ & 3.38 & 2.35 & 4.70 & 20.19 & 21.07 & 92.00 & 1.35 & 39.87 \\
\hline 7 & Fruit length $(\mathrm{cm})$ & 9.50 & 5.43 & 12.52 & 16.88 & 17.95 & 88.00 & 3.11 & 32.71 \\
\hline 8 & Fruit weight (g) & 233.02 & 154.25 & 570.00 & 44.70 & 45.10 & 98.00 & 212.64 & 91.25 \\
\hline 9 & Length of pedicel $(\mathrm{cm})$ & 2.26 & 1.15 & 3.63 & 30.67 & 31.27 & 96.00 & 1.40 & 61.95 \\
\hline 10 & Pedicel thickness (mm) & 16.45 & 11.25 & 25.75 & 29.61 & 30.16 & 96.00 & 9.85 & 59.87 \\
\hline 11 & Length of pericarp $(\mathrm{cm})$ & 2.01 & 1.35 & 3.35 & 29.29 & 29.61 & 98.00 & 1.20 & 59.69 \\
\hline 12 & Weight of pericarp (g) & 3.45 & 2.28 & 5.85 & 29.60 & 30.22 & 96.00 & 2.06 & 59.71 \\
\hline 13 & Seed length (mm) & 20.50 & 15.50 & 24.00 & 10.37 & 12.08 & 74.00 & 3.76 & 18.34 \\
\hline 14 & Seed width (mm) & 7.70 & 5.50 & 8.75 & 9.00 & 11.44 & 62.00 & 1.12 & 14.57 \\
\hline 15 & Number of seeds/ fruit & 31.55 & 25.75 & 35.50 & 6.94 & 8.78 & 62.00 & 3.56 & 11.29 \\
\hline 16 & Seed weight (g) & 32.47 & 23.88 & 35.55 & 9.05 & 11.06 & 67.00 & 4.96 & 15.26 \\
\hline 17 & Pulp weight (g) & 114.46 & 72.29 & 302.10 & 52.16 & 52.46 & 99.00 & 122.27 & 106.82 \\
\hline 18 & Areole weight (g) & 78.36 & 47.46 & 205.20 & 51.47 & 51.80 & 99.00 & 82.55 & 105.35 \\
\hline 19 & Number of fruits/ tree & 305.63 & 284.75 & 376.00 & 6.86 & 8.51 & 65.00 & 34.84 & 11.40 \\
\hline 20 & Fruit yield/ plant (kg) & 113.89 & 101.25 & 152.25 & 16.13 & 17.04 & 90.00 & 35.81 & 31.44 \\
\hline
\end{tabular}

\section{Genetic advance as percentage of mean}

The data of genetic advance as percentage of mean for observation are presented in Table 3 . Among 20 characters studied, the highest genetic advance as percentage of mean was observed for pulp weight (106.82), followed by areole weight (105.35), fruit weight (91.25), length of pedicel (61.95), pedicel thickness (59.87), weight of pericarp (59.71), length of pericarp (59.69), total number of fruits per plant (45.07), fruit width (39.87), fruit length (32.71), fruit yield per plant (31.11), number of flowers per branches (19.18), seed length (18.34), length of leaf (15.52), seed weight (15.26), seed width (14.57), number of fruits per tree (11.40), number of seeds per fruit (11.29), number of alternate leaf (7.66) and days to $50 \%$ maturity (3.09). Similar results have also been reported by Keny and Paulo (2009), Paulo et al., (2009) and Bhatnagar et al., (2012).

The highest genetic advance was observed for fruit weight (212.64) followed by pulp weight (122.27), areole weight (82.55), number of fruits per tree (34.84), fruit yield per plant (35.81) and number of alternate leaf (24.58). The moderate genetic advance was not observed for the character, rest of the traits showed low genetic advance by George et al., (1999).

\section{Genetic advance as percentage of mean}

The data of genetic advance as percentage of mean for observation are presented in Table 3 . Among 20 characters studied, the highest genetic advance as percentage of mean was observed for pulp weight (106.82), followed by areole weight (105.35), fruit weight (91.25), length of pedicel (61.95), pedicel thickness (59.87), weight of pericarp (59.71), length of pericarp (59.69), total number of fruits per plant (45.07), fruit width (39.87), fruit length (32.71), fruit yield per plant (31.11), number of flowers per branches (19.18), seed length (18.34), length of leaf (15.52), seed weight (15.26), seed width (14.57), number of fruits per tree (11.40), number of seeds per fruit (11.29), number of alternate leaf (7.66) and days to 50\% maturity (3.09) Similar results have also been reported by Keny and Paulo (2009), Paulo et al., (2009) and Bhatnagar et al., (2012).

In the present investigation, high heritability 
coupled with high genetic advance as percentage of mean was found for pulp weight, followed by areole weight, fruit weight, weight of pericarp, pedicel thickness, length of pericarp and length of pedicel, which indicated the predominance of additive gene action in the expression of these characters which could be utilized through selection for improvement in these characters. Rest of the traits showed high to moderate heritability estimates coupled with moderate to low genetic advance as percentage of mean indicated the role of non- additive genetic variance in their expression Similar results have also been reported by Islam et al., (1991), Jagtap and Kokate (1991), George et al., (1999), Carvalho et al., (2000), Wang et al., (2001) and Saulo et al., (2006).

\section{Acknowledgements}

The first authors wish to acknowledge Department of Horticulture, College of Agriculture, IGKV, Raipur (CG) for providing for education and research programme. I also express my thanks to Dr. Ajay Tiwari (Contractual Teacher) College of Agriculture and Research Station, Kanker (C.G.), IGKV Raipur for making the manuscript.

\section{References}

Anonymous. 2013. Indian Horticulture Database. National Horticulture Board, India. pp: 6-14.

Bhatnagar, P., Singh, J., Jain, M.C. and Singh, Bhim. 2012. Evaluation of landraces of custard apple (Annona squamosa L.). Plant Archives, 12: 1045-1048.

Burton, G.W. and Vane, E.M. 1952. Estimating heritability in fall fescue (Festuca circunclinaceae) from replicated clonal material. Agron. J., 45: 478-481.

Carvalho, P.S. de, Bezerra, J.E.F., Lederman, I.E., Alves, M.A., and Melo Neto, M.L.de. 2000. Performance of custard apple (Annona squamosa L.) genotypes in the Moxoto River Valley. Revista. Brasileira. de. Fruticultura, 22: 27-30.
Chandra, A. 2010. Participatory approaches in precision farming. In: Souvenir of National Seminar on Precision Farming in Horticulture, College of Horticulture and Forestry, Jhalawar, p: 650-657.

George, A.P., Broadley, R., Nissen, R.J., Hamill, S.D. and Topp,B. 1999. Breeding strategies for atemoya and cherimoya. Acta Horticulturae, 49: 255-267.

Gopalan, C. Rama, Shastri, B.V. and Balasubramanin, S.C. 1987. Nutritive value of Indian Foods. NIN, ICMR, Hyderabad, p.93

Hanson, W.D., Robinson, H.F. and Comstock, R.E. 1956. Biometrical studies of yield in segregating population Korean Lespandeza. Agron. J., 4: 268-272.

Jagtap, K.B. and Kokate, A.S. 1991. Promising custard apple (Annona squamosa L.) selections from Pemgiri (Sangamner) region in Ahmednagar Dist. of Maharashtra. Maharashtra J. Hort., 5: 41-44.

Johnson, H.W., Robinson, H.F. and Comstock, R.E. 1955. Estimates of genetic and environmental variations in Soybean. Agron. J., 4: 314-318.

Keny, H.M. and Paulo S. L., e S. 2010. Relationship between fruit traits of custard apple trees (Annona squamosa L.). Revists Ceres, 57: 231233.

Paulo, S., Lima, e. S., Rafaela, P. A., Keny, H.M., Kathia, M.B.e.S., Lidiane, K.de. L. and Julio, C.do. V.S. 2009. Estimates of genetic parameters for fruit yield and quality in custard apple progenies. Revista. Brasileira de Fruticultura, 29: 155-159.

Saulo, A.S., Ana, C.V. L.D, Simone, O.A. and Vanessa, A. 2006. Fruit characterization of sugar apple genotypes in Presidente Dutra, Bahia. Crop Breeding and Applied Biotechnology, 8: 295-302.

Singh, R.K. and Choudhary, B.D. 1985. Biometrical methods in quantitative genetics analysis. Kalyani Pub., Ludhiana, India.

Wang, J.C.Y. and Luo, S.R. 2001. Study on the effect of rootstocks on the growth and fruit quality of custard apple variety "African Pride". China Fruits. 6: 23.24.

\section{How to cite this article:}

Jeevan Lal Nag, N. Shukla and Ajay Tiwari. 2018. Characterization of Custard Apple (Annona squamosa L.) Genotypes at Northern Bastar of Chhattisgarh, India. Int.J.Curr.Microbiol.App.Sci. 7(02): 1700-1707. doi: https://doi.org/10.20546/ijcmas.2018.702.205 